\title{
BRASIL. COPA DO MUNDO 2014: ANÁLISE DOS IMPACTOS AMBIENTAIS, ECONÔMICOS E SOCIAIS
}

\author{
Lucas Porciuncula Porto ${ }^{1}$ \\ Lucas Freier Ceron ${ }^{2}$ \\ Luiz Ernani Bonesso de Araújo ${ }^{3}$
}

\begin{abstract}
RESUMO
O presente artigo tem por objetivo analisar os impactos ambientais, econômicos e sociais que a construção dos estádios sede da Copa do Mundo gerará para o Brasil, principalmente nas localidades em que serão construídas. Pretende - se abordar neste trabalho uma visão geral de como as obras e as infraestruturas geradas afetarão as comunidades que serão removidas de suas casas. Não bastassem os impactos sociais têm-se como outro grave problema os impactos ambientais. É certo que o evento gerará ganhos econômicos em benefício de uma parte da população e, causando problemas para os setores da população mais fraca economicamente. Esses fatos podem ser enquadrados como um problema de justiça ambiental. Nesse sentido a análise se voltará para a relação entre os impactos e seus efeitos para a população atingida. Como método de pesquisa utiliza - se o método indutivo, pois se analisará os efeitos impactantes e sua relação com as noções de sustentabilidade e justiça ambiental.
\end{abstract}

PALAVRAS-CHAVE: Copa. Impactos. Justiça Ambiental.

\section{INTRODUÇÃO}

O slogan, divulgado na mídia no período em que o Brasil foi escolhido sede da Copa do Mundo de 2014, “a copa vai acabar, mas o desenvolvimento vai ficar", faz iniciarmos o presente artigo com a seguinte indagação: Desenvolvimento para quem?

Em meados de Outubro de 2007, a FIFA anunciou que a sede da Copado Mundo de 2014 seria o Brasil para a alegria de uns e tristeza de outros. Deve se ter em mente que o último evento realizado no país foi em 1950 em uma época muito diferente que a atual.

Atualmente o compromisso de um país em sediar um dos maiores eventos futebolísticos do mundo requer, além de vontade, estudos aprofundados para que as obras realizadas não cause nenhum prejuízo para a população e nem ao meio ambiente.

Não se pode negar que em termos econômicos a realização da Copa do Mundo trará inúmeros benefícios para o Brasil. Apenas para ter uma ideia a economia deslanchará

\footnotetext{
1 Autor. Acadêmico do $6^{\circ}$ semestre do curso de Direito da Universidade Federal de Santa Maria. Integrante do Grupo de Pesquisa em Direito da Sociobiodiversidade (GPDS). Email para contato: porto.poporto@ hotmail.com. Telefone: (55) 99113725

${ }^{2}$ Coautor. Acadêmico do $8^{\circ}$ semestre do curso de Direito da Universidade Federal de Santa Maria. Integrante do Grupo de Pesquisa em Direito da Sociobiodiversidade (GPDS). Email para contato: lucasceron@gmail.com

${ }^{3}$ Orientador. Professor do curso de Direito da Universidade Federal de Santa Maria. Coordenador do Grupo de Pesquisa em Direito da Sociobiodiversidade (GPDS).
} 
III SEMINÁRII ECDLOGIA

POLÍTICA

Ocorre que a Copa do Mundo é um evento de abrangência nacional e por isso os estudos não poderão ficar focado apenas em uma única cidade. Serão abordados os impactos em geral que irão ocorrer pelo país.

Um dos principais problemas sociais a serem enfrentados na realização da Copa é relacionado à moradia. Consagrada como um direito básico em nossa constituição parece estar sendo esquecida pelo Poder Público.

Não faltam relatos de moradores em comunidades carentes, onde a pobreza e a falta de recursos são um grave problema a ser sanado, de ameaças por meio das empresas construtoras com o intuito de intimidar aqueles que por sua condição não conseguem fazer valer os seus direitos.

Prática muito comum essa da ameaça, tendo em vista que grande parte destes moradores ocupam as áreas de maneira irregular e na visão das construtoras os mesmos teriam que sair independentemente de possuir ou não condições de adquirir outra moradia em local legalmente permitido.

Neste viés, desde o momento em que foi anunciada a realização do evento no Brasil e a notificação das famílias à necessidade de deixar suas moradias para dar lugar às construções que sediarão a Copa do Mundo, grande parte destes moradores se queixa da falta de informações do Poder Público deixando - os cada vez mais preocupados em relação ao futuro.

Ainda, tratando dos problemas sociais, não se pode deixar passar o do estádio de Itaquera, tendo o local de sua construção uma alta valorização e com isso gerando a expulsão dos residentes daquele local, em virtude de não possuírem condições de manterem o aumento no padrão de vida que ali se estabelecerá.

Segundo uma publicação realizada no dia 03 de Abril de 2012 no site Le Monde Diplomatique Brasil, no município de São Paulo, especificamente no bairro do Itaquera, está sendo realizada a construção do estádio do Corinthians que será palco da estreia da Copa do Mundo de 2014. A construção da obra chama a atenção pelo fato de que depois de realizada aumentará muito o custo de vida do local onde reside gente de classe média baixa. Isto não ocorre apenas em Itaquera, mas em qualquer local que recebe um megaempreendimento, acaba se tornando algo natural, lei da oferta e procura.

A construção do estádio fará com que muitas famílias tenham que ser remanejadas para outros locais. A parte positiva desta situação, ou que pelo menos 



Talvez um grande desafio para o governo não seja de onde captar recursos, pois atualmente existem inúmeras formas de financiamentos e acredita-se que obter o dinheiro não seja a maior incógnita.

Provavelmente com as construções e infraestruturas construídas para o evento o Brasil possa avançar em uns 20 anos, somente sendo possível com um planejamento adequado do poder público para que não haja desperdícios.

A grande questão que pode gerar um impacto negativo em longo prazo não é de onde captar verbas para a construção dos estádios e sim de onde captar recursos para a manutenção dos mesmos após a realização do evento.

Este não é apenas um problema do Brasil. Em outros eventos como da Copa da África em 2010 pode se ver bem qual foi o legado deixado pelo evento. Com um investimento aproximado de 8 bilhões, a África do Sul levantou cinco estádios e construiu a estrutura necessária para a realização dos jogos.

No entanto, dois anos após o término da Copa a África do Sul contabiliza os prejuízos com a manutenção desses estádios. Só o custo de um deles é de aproximadamente R \$ 10,5 milhões por ano.

$\mathrm{O}$ alto custo de manutenção e os investimentos não recuperados podem fazer do evento após seu término um enorme impacto para os cofres do governo. Serão gastos no Brasil para a realização da Copa praticamente os valores gastos nas três últimas edições do mundial: Coréia e Japão (2002) - US\$ 16 bilhões, Alemanha (2006) - US\$ 6 bilhões, e África do Sul - US\$ 8 bilhões.

A realização deste evento não irá gerar ganhos para a população em um todo e para afirmar basta realizar uma interpretação da lei 12. 663/12 (Lei Geral da Copa) que dispõe sobre as medidas relativas à Copa do Mundo FIFA 2014. A lei em questão aborda uma série de empecilhos, constituindo o direito de patentes e de exclusividade comercial à FIFA e o monopólio de mercados, dando prioridades de apenas alguns poucos auferirem renda com o evento.

Segundo o Art. 11 da "Lei Geral da Copa" estão terminantemente vedados à possibilidade de trabalhadores informais auferirem renda em uma área de $2 \mathrm{~km}$ em torno do evento. Tal prática mostra a força das empresas multinacionais e a forma com que a FIFA está interferindo para que o monopólio das empresas parceiras predomine em território nacional. 




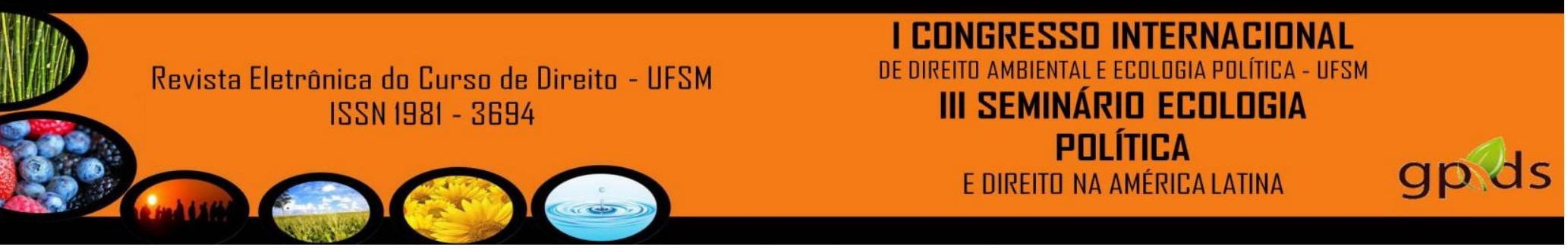

http://www.planalto.gov.br/ccivil_03/constituicao/ConstituicaoCompilado.htm. Acesso em 06/09/12.

http://www.planalto.gov.br/ccivil_03/_Ato2011-2014/2012/Lei/L12663.htm. Acesso em 06/09/12.

Rede social brasileira por cidades justas e sustentáveis. http://redciudades.net/blog/?p=975. Acesso em 03/09/12. 